AWEJ for Translation \& Literary Studies, Volume2, Number 1, February 2018

DOI:http://dx.doi.org/10.24093/awejtls/vol2no1.6

\title{
Postmodern Picture Books as Multimodal Texts: Changing Trends in Children's Literature
}

\author{
Shaju Ouseph Nalkara \\ Department of English, Faculty of Language Studies \\ College of Language and Literature, Arab Open University \\ Riyadh, Saudi Arabia
}

\begin{abstract}
:
Literature for children has undergone significant changes over the past years. It has generated new attitudes towards childhood and changing practices around literature. The concept of literature for entertainment along with instruction, as proposed by Peter Hunt, has changed the traditional mode of reading methods and gave new dimensions in reading and experiencing children's books. Nowadays, children's books are available in various forms like printed books, audio/video recordings, animated movies, Disney cartoons etc. New developments in computational field and digital media have opened wider ways of exploring children's stories. This has also led to the notion of cross-reading. Most of the stories for children are re-told or re-visioned adapting to different socio-cultural, linguistic domains. This adaptation is both a product and process as seen by Hutcheon (2012). The chief characteristics of postmodern picture books include usually a nonlinear plot structure, using pictures or texts to position the reader and focalizing ideas through the point of view of a character, construction of meaning by the reader, intertextual references and above all, the varied design layout and styles of illustration as envisioned by Anstey (2002). All these developments appease the tastes of the modern child as well as the adult reader. This paper is an attempt to explore the evolving styles in contemporary children's books where it is thought of more in terms of multimodal texts, with self-referential elements adding to it the notion of metafiction.
\end{abstract}

Keywords: children's literature, multimodality, picture books, postmodern, media

Cite as: Ouseph Nalkara, S. (2018). Postmodern Picture Books as Multimodal Texts: Changing Trends in Children's Literature. Arab World English Journal for Translation \& Literary Studies, 2 (1). DOI:http://dx.doi.org/10.24093/awejtls/vol2no1.6 


\section{Introduction}

Childhood is a fluid concept and not a stable one. In the postmodern era, the notion of childhood as a time of innocence is challenged by the ideology of consumerist capitalism. It is also endorsed by modern media's intrusion into the life of the people, including those of children's. Violence, sex and all sorts of abuse are inflicted in various forms to the modern child through different mediums. Contemporary commercial trends have immensely affected the temperament and attitude of the modern child. They are incredibly aware of the events and practices prevailing in society and are capable of facing the challenges of the world, if not all, but many. In addition to that, the inescapable presence of multimedia offers various complex situations and suggests ways of dealing with it. Thus, the modern child, consciously or unconsciously, gains confidence to survive and exhibits strategies of existence that they gained through these representations.

Children's books are obtainable now in different forms. The stories presented in the form of picture books make use of graphics in literary texts for children. It can be seen at various levels, starting from the look and feel of book, to the role that visual information plays in framing story and even the typography that is used to create meaning and emotional impact. Words and images of different kinds are usually blended to form narratives for children, sometimes in intricate ways. For example, in Browne's (2001) Voices in the Park, the sections referring to different voices and characters are presented in varied font styles which represent their social class and status.

\section{Literature Review}

Scholars and critics have been interested in the narrative techniques employed in picture books. Bang (2000), an American illustrator in her book Picture This shows how a fairy tale can be visually portrayed with the aid of various shapes. She uses a simple red triangle at the beginning, and later complements with 'trees' when the story progresses as a visual representation of the fairy tale Little Red Riding Hood. She resizes the character to make her look smaller and moves her further from the foreground to stress her vulnerability. In doing so, Bang expects the reader's/spectator's background knowledge of the fairy tale to come into play with the picture. This is made possible by showing simultaneously the surface simplicity and deeper complexity of knowledge of the reader while reading, seeing and understanding picture books. Lehman (2004) is another American author/illustrator who is renowned for her artworks of rare detail and surprise. Her work crosses oceans and continents to deliver one girl into a new world of possibility, where a friend she is never met is waiting. Potter (1902) applies a similar strategy in her representation of images in The Tale of Peter Rabbit and similar series of picture books. The illustrators of picture books in general, create the best possible images or pictures even in the cover page in order to convey the theme and centrality intended by the author of the book.

In the last three decades, according to Mikkelsen (2000), picture books have become 'increasingly experimental, with thematic complexities and sophisticated artistry that have entirely changed their look' (p.31). Whalley and Chester (1988) trace the development of illustrated books for children to their early beginnings in $17^{\text {th }}$ century. Majority of early books were made on cheap paper with primitive printing technology. According to Whalley (2009), it was unattractive to both children and adults. She observes that illustrations were not properly used when they were reproduced. However, what is unique and particular to present day picture books is its massive range of diverse narrative styles and formats. In fact, she draws a subtle distinction between 'books 
with pictures' and 'illustrated books.' In her opinion, well-illustrated books are those where pictures are of high quality and enhance the story. It is a fact that there is a difference in the terminology used by historians and analysts of illustrated books for children. 'Illustrated books' are those where pictures enhance the book aesthetically, but add nothing or little to actual story. Here, story holds good without pictures and images have a decorative function, making the book more appealing to the children. Whalley (2009) believes, "a bad illustrated book is one where the pictures lack relevance to the text and poorly drawn or reproduced". In short, where illustrations are simply reproduced, they are not always well used.

\section{Picture Books}

Before analyzing the various definitions, it has to be mentioned that the deliberately unseparated 'picturebook' is used for books for children in which visuals are essential to the narrative. It is the one where words and images work together. They cannot be separated without radically affecting the meaning. Sometimes, much of the narrative is conveyed by images alone. Bader (1976) defines:

A picturebook is text, illustrations, total design; an item of manufacture and a commercial product; a social, cultural, historical document; and foremost an experience for a child. As an art form it hinges on the interdependence of pictures and words, on the simultaneous display of two facing pages, and on the drama of the turning of the page. (p.1)

Picture books provide a world for the child to explore by encouraging him or her to move forward with the story in a curious way.

But, the intentionally separated 'Picture book' is understood as the one where words and images basically show same idea or same parts of the story. One can easily comprehend the same story with the help of either words or pictures and Rev. W. Awdry's (1946) Thomas the Tank Engines series will be an excellent example in this regard. Still, these definitions may seem problematic and one can perhaps reasonably choose the works of Brown (2001) and Potter (1901) as picture books in the fullest sense in that they utilize images as narrative device. In the former, images cannot be removed to leave a story that would be impoverished whereas in the latter, pictures enhance our understanding of chain of events, Peter's attitude and his character.

Sutherland and Hearne (1977) explain that "a picture book is one in which the pictures either dominate the text or are as important" (p. 158) and their aim is to include "the broadest possibilities of the genre" (p. 160). Kiefer (1995) mentions the "picture storybook, in which the story and pictures are of equal importance and they form an artistic unit that is stronger than either of them would be alone" (p. 9). They claim the criterion of interdependence of the text and an illustration adding to what Marantz (1977) explains as:

"a picture book, unlike an illustrated book, is properly conceived of as a unit, a totality that integrates all the designated parts in a sequence in which the relationships among them-the cover, endpapers, typography, pictures - are crucial to understanding the book" (p. 3). 
In semiotic terms, each part of the picturebook functions as a sign and has a tremendous potential to contribute meaning to the book.

\section{Integration of Words and Images}

Picturebooks, with total integration of word and image emerged by the second half of $20^{\text {th }}$ century. Salisbury (2004) who is an illustrator by profession refers to some aspects of successful picture books highlighting how images and words can be made to work in coordination with each other. He explains the publication of these books for different geographical markets and ways in which researchers and artists looked at these texts. They focus on education, literacy development and art itself. Illustrators and authors may work together, or one person may craft a picturebook in its totality. Salisbury uses the term 'authorstrator' to emphasize that illustrator has an authorial voice in a completed text. He makes a comparison with pictures in children's books similar to storytelling or equal to that of words and thus they are more appealing to both children and their parents. Hunt's (1994) notion of instruction with delight is exemplified in the case of modern picture books.

Pictures in children's books are not often simple, innocent, childish and unchallenging things that they seem to be; rather they are complex and conveying a deeper meaning. Many analysts of children's illustration highlight the fantastic sophistication and artistry of images and their combination in telling stories. For example, Nodelman (1988) refers to Burningham's $\mathrm{Mr}$ Gumpy's Outing (1970) in this context as it demands cultural, social and textual conventions in its analysis.

\section{Changing Trends}

An example of a less traditional book is Tan's The Lost Thing (2000) which tells a somewhat bleak tale, set in a faceless industrial and highly conformist environment where the houses and people look same. The boy narrator ultimately finds a place where the Thing seems happy to stay as he is concerned of its well-being. Mallan (2005) analyses it as Tan's comment on the social condition of (post)capitalist, post-industrial societies (p. 215). The words in The Lost Thing are remarkably straightforward, telling a simple story with no particular political or social commentary (p. 213). The depiction that Mallan notes, of 'obsolete post-industrial urban space', is primarily in images and the text itself is included as part of the image.

In certain instances, picture books use only few words, but this does not make them simple. For example, Wiesner's Tuesday (1991) conveys the 'voice' of the narrator through its rich visuals in fulfilling its purposes. The book has only twelve words in total; however, readers read through the images in the book. Thus the narrative role is transferred to the reader. Similarly, the Caldecottprizewinning book by Wiesner 'Flotsam' (2006) and Hughes's Up and Up (1979) contains no words at all. Researchers and critics testify that even very young children are highly capable of 'reading' stories in similar texts that tell tales through images. They question and interpret the pictures, their combination and sequencing (Styles, 1996).

The question of 'audience' for picturebooks has a major role in its analysis. Many books are intended to attract to both young children and adults who read along with them. In fact, various strategies are used to achieve this. There are books where information, allusions or visual or verbal

Arab World English Journal for Translation \& Literary Studies 
jokes are made in text. Later expansion of readership for picture books into older age range is noted by Kiefer (1995):

“...picturebooks are showing up not only in the upper elementary school grades but also in middle school and high school classrooms. In addition, adults seem to be discovering picturebooks; several of those published for the children's market have reached the adult best-seller list of The New York Times" (p.70)

\section{Visual Intertextuality}

An important way in which picture books reach adult readership is through the use of intertextuality, where one text makes references or allusions to another. Visual intertextuality is applied in terms of picture books, where images refer to other images to fulfill the purpose. Browne's Voices in the Park employs this technique. Sendak's creatures in Where the Wild Things Are (1963) have visual intertextual connections with Picasso's art (1937). Jones (2008), writing in the Guardian newspaper, points to the similarity between them:

Max is a child of nature. Sent to bed by his mother, he imagines that a forest grows in his room, and a forest really does grow in his room. ...And then Max sets sail to the land of Wild Things, still wearing his wolf suit, and leads a gang of gigantic beasts in howling at the moon, swinging in the trees and having a tumultuous parade....Sendak's monsters resembles the minotaur in Picasso's 1937 print Minotauromachy. In that work, Picasso, too, stresses the courage and innocence of children: a girl stands undauntedly holding up a candle to illuminate the Minotaur's horror while a grown man runs away.

Likewise, Potter's illustration in The Tailor of Gloucester (1903) has similar visual connection with the painting Cherry Ripe (1880) by the artist John Everett Millais.

Wilkie-Stibbs (2005) identifies that children's intertextual knowledge is not always adequately developed to understand these visual connections fully. Many adults are also likely to miss them. Some allusions are deliberately made whereas others are not. Certain meanings inferred from the text may be reader's interpretation than what is intended by the author or illustrator. Adults and children notice different references and allusions based on their experience and knowledge. Intertextuality of a more literal kind is also present in the material form of some books for young children.

Picture books play a vital role in children's literature and literacy practices. Educators or adults use them in diverse ways to enhance their cognitive, learning, writing and readings skills. Picture books provide a unique world for children with its holistic approach where text and pictures, covers and end pages and other artistic design works remain interconnected. Images or pictures in children's books serve a variety of purpose, including form, content and style. More than presenting a fine spectacle, they form a visual narrative where images tell more than words of the text, and thus convey multilayered meanings and interpretations. 


\section{History of Children's Literature}

The history of illustrated children's literature runs back to 15 th century, during the early budding of print technology in Europe, where it was available in many forms. Kiefer (1995) comments that the idea of picture book as a visual/verbal art with intellectual or emotional resources could be dated back to 40,000 years ago. She stresses the reading experience of visual storytelling texts, other than the physical shape of the kind of books that are available at present. Examples of such inscriptions include Aboriginal 'dreaming' of traditional indigenous Australian art, European cave paintings that acts as precursors of modern written or printed storytelling, Bayeux Tapestry, Egyptian hieroglyphics etc. Although these art forms were not basically aimed at children, it opened up wider textual possibilities to many modern storytellers to re-version and reform to suit the taste of modern child. Earliest printed stories for children were available as woodcut illustrations in black and white, lacking enough details. $19^{\text {th }}$ century technological progress was instrumental in generating full-colour reproduction of children's picture books. This also resulted in widespread readership of children's books.

Moebius (1986) is a chief contributor to the field of visual stylistics. It has its roots in structuralism and semiotics, which led to modern studies in multimodality. It explores visual elements of texts that combine with words create meanings for readers or viewers. The picture books demand deep textual analysis than being categorized as 'simple' or aimed only at children. Images should not be looked at in isolation from the surrounding text. They have a context, a sequence and meaning is derived from their positioning in the text and in their interaction with words. Interpretation is not fixed; allusions and intertextuality may be present in the text. It becomes relative based on the reader or viewer, as these children's books are revisited from time to time. Nodelman (1988) recognizes the nature of picture books as cultural artefacts reflecting societal mores, values and beliefs. It exhibits extraordinary flexibility, openness and inventiveness due to its brevity, interplay of narratives and illustrations. Goldstone (2004) explores the subject of postmodern picture books and focus on the idea of how authors play with the concept of space. The traditional three-dimensional space could be manipulated into five dimensions, to include that between the book and the reader, is the space 'beneath the physical page'- open for characters to step into.

Picture book pages, text and illustrations can evaporate, multiply, pile up on top of one another, peeled back and even constructed into things other than picture book parts. These books include playfulness, parody, self-referentiality, nonlinearity, multiple perspectives and irony. In postmodern picture books, the characters see the audience, speak with them and move outward and into their space. Anstey (2002) in "It's not all black and white" refers the salient features of postmodern picture books: It involves non-linear narrative forms or non-traditional plot structure; It uses the text or pictures to position the reader to read the text in a particular way through character's point of view; In invites reader's involvement in constructing the meaning of the text; Intertextual references are included where the reader is able to make connections to other books and gain better understanding of the text; It has varied design, layout and styles of illustration. The major postmodern Children's Books include the following: Macaulay's Black and White (1990), Wiesner's The Three Pigs (2001), Browne's Voices in the Park (1998), Scieszka and Smith's The Stinky Cheese Man (1992) and Legge's Bamboozled (1994). 
AWEJ for Translation \& Literary Studies Volume, 2 Number 1, February 2018

Postmodern Picture Books as Multimodal Texts: Changing Trends

Ouseph Nalkara

\section{Interaction with Text and Illustration}

Recent studies by Serafini (2004) examine how text interacts with illustrations. Three sets of books are discussed in his study: books that have corresponding texts and pictures, books where illustrations enhance texts and books where illustrations contradict texts. Postmodern picture books may be ambiguous to children and allow for multiple interpretations. However, books that are open to interpretation include the first three in the examples mentioned above. Ryan and Anstey (2003) observe that the postmodern picture books are able to increase the 'self-knowledge about reading' of children. They can use this knowledge in strategic ways as they read these books. The classic example is The Rabbits (1998) by Marsden and Tan. As for Benton (1994), the reader or viewer becomes an 'insider', fully lost in text and time at the moment. It is a counter action to the characters who becomes 'outsiders' to the traditional texts. This is illustrated in Wiesner's (2001) picture book, where the wolf not only huffs, puffs and blows down the house, but also blows the pig out of the story. The texts lose its temporal quality, as texts and images are intricately blended in picture books. Writing is now 'display oriented' as envisioned by Kress (2003). These trends can be located within the discipline of reader-response theory. The artists or authors of these texts present a new visual world of experience for the modern child and a new way of seeing, which is accomplished through multimodal texts. Reading thus becomes a new pattern of experiencing, where images and words become blended. The text resists and challenges the traditional, linear, chronological practices of reading and visualizing stock characters.

\section{Conclusion}

This paper was an attempt to explore the significant stylistic changes that took place in the postmodern picture books. It is evident that one can witness progressive styles in contemporary children's books, producing it as multimodal texts, with self-referential elements in it. The modern commercial trends and advancement of multimedia have influenced and imposed new experiments in this field. For the modern child, visuals are as important as the narrative. Publishers are deeply concerned with their product design and how effective they are in providing a complete experience to the children. To make it happen, the stories are re-told or re-visioned, adapting to different sociocultural and linguistic domains. This results in intertextual and intra-textual references, making connections with other books to gain better understanding. Hence, any demonstration and adaptation can be seen as both, a 'product' and 'process.' With the help of visual stylistics, visual elements are combined with words to create meaning for its readers. Postmodern picture books are non-linear narratives where text or picture is used to position the reader and his involvement is vital in constructing the meaning. Postmodern authors reflect on a world - complex and confusing, a world which questions its purpose and function, and has unstable and changing boundaries. To convey these insights, they present a new visual world and a new way of seeing.

\section{About the Author:}

Shaju Ouseph, Nakara is Assistant Professor of English literature. He has an MA \& M.Phil in English language and literature, and a $\mathrm{PhD}$ in African-American literature. His research interests include African-American writings, Teaching Methodology and ICT in ELT. He is the coordinator of FLS programme at AOU. 
AWEJ for Translation \& Literary Studies Volume, 2 Number 1, February 2018

Postmodern Picture Books as Multimodal Texts: Changing Trends

Ouseph Nalkara

\section{References}

Awdry, W. (1946). Thomas the Tank Engine. London: Heinemann.

Anstey, M. (2002). "It is not all black and white". Postmodern Picture Books and New

Literacies. Journal of Adolescent \& Adult Literacy. 45 (6), 444-458.

Bader, B. (1976). American Picture Books from Noah's Ark to the Beast Within. New York: MacMillan.

Bang, M.(2000). Picture This: How Pictures Work, New York: Sea Star.

Benton, M. (1994). 'The Self-Conscious Spectator'. The Centre of Language in Education, University of Southampton. Occasional Papers, 30:1-22.

Brown, A. (2001). Voices in the Park. New York: DK Publishing.

Burningham, J. (1970). Mr. Gumpy's Outing. London: Cape.

Goldstone, B.P. (2004). The postmodern picture book: A new subgenre. Language Arts, 81(3), 196-204.

Hughes, S. (1979). Up and Up. London: Random House Children's Books.

Hunt, P. (1994). An Introduction to Children's Literature. Oxford, OUP.

Hutcheon, L. (2012). A Theory of Adaptation. London: Routledge.

Jones, J.(2008). 'Wild Things, I think I love you', The Guardian (online) 12 April, http://www.guardian.co.uk/books/2008/apr/12/booksforchildrenandteenagers.features (accessed 14 February 2017).

Kiefer, B.Z. (1995). The Potential of Picture Books: From Visual Literacy to Aesthetic Understanding. Englewood Cliffs, NJ, Prentice-Hall.

Kress, G. (2003). Literacy in the New Media Age. London: Routledge.

Legge, D. (1994). Bamboozled. Scholastic: New York.

Lehman, B. (2004). The Red Book. Boston: Houghton Mifflin.

Macauley, D. (1990). Black and White. New York: Houghton Mifflin.

Mallan, K (2005). Trash aesthetics and utopian memory: The Tip at the End of the Street and The Lost Thing. Bookbird, 43 (1), 28-34.

Marantz, K. (1977). The picture book as art object: A call for balanced reviewing. Wilson. Library Bulletin, 148-151.

Marsden, J \& Tan, S. (1998). The Rabbits. Sydney: Hodder.

Mikkelsen, N. (2000). Words and Picures : Lessons in Children's Literature and Literacies. Boston: McGraw.

Millais, J.E (1880). Cherry Ripe. London: Royal Academy of Arts (RA).

Moebius, W. Introduction to picture book codes. Word and Image, 2:2 (1986), 141-158.

Nodelman, P. (1988). Words about Pictures: The Narrative Art of Picturebooks. Athens, GA: University of Georgia Press.

Potter, B. (1902). The Tale of Peter Rabbit. London: Frederick Warne.

Ryan, M., \& Anstey, M. (2003). Identity and Text: Developing Self-conscious Readers. Australian Journal of Language and Literacy, 26(1), 9-22.

Salisbury, M. (2004). Illustrating Children's Books: Creating Pictures for Publication. London: A\&C Balck/Qarto.

Scieszka, J \& Smith, L. (1992). The Stinky Cheeseman and Other Fairly Stupid Tales. London: Puffin.

Sendak, M. (1963). Where the Wild Things Are. New York: Harper and Row.

Arab World English Journal for Translation \& Literary Studies 
AWEJ for Translation \& Literary Studies Volume, 2 Number 1, February 2018

Postmodern Picture Books as Multimodal Texts: Changing Trends

Ouseph Nalkara

Serafini, F. (2004). Lessons in Comprehension: Explicit Instruction in the reading workshop. Portsmouth, NH: Heinemann.

Styles, M. (1996). Inside the tunnel: a radical kind of reading-picture books, pupils and postmodernism. In Watson, V. \& Styles, M (Eds.), Talking Pictures: Pictorial Texts and Young Readers. London: Hodder and Stoughton.

Sutherland, Z., \& Hearne, B. (1977). In search of perfect picture book definition. Wilson Library Bulletin, 158-160.

Tan, S. (2000). The Lost Thing. Melbourne: Thomas and Lothian.

Whalley, J.I. (2009). Texts and Pictures: A History. In Janet. M \& N. Watson (Eds.), Children's Literature: Approaches and Territories (pp.299-310). Milton Keynes: Palgrave Macmillan.

Whalley, J.I \& Chester, T.R. (1988). A History of Children's Book Illustration. London: John Murray, with the Victorian and Albert Museum.

Wiesner, D. (2006). Flotsam. New York: Clarion.

Wiesner, D. (2001). The Three Pigs. New York: Houghton Mifflin.

Wiesner, D. (1991). Tuesday. New York: Clarion.

Wilkie-Stibbs, C. (2005). 'Intertextuality and the child reader'. In Hunt, P (ed.). Routledge International Companion Encyclopedia of Children's Literature ( $2^{\text {nd }}$ edn), London: Routledge.

Arab World English Journal for Translation \& Literary Studies 